\title{
International Unit per Minute
}

National Cancer Institute

\section{Source}

National Cancer Institute. International Unit per Minute. NCI Thesaurus. Code C85647.

International units per minute. 